\title{
ПРОЦЕДУРА МЕДІАЦІЇ У ВИРІШЕННІ ЦИВІЛЬНО-ПРОЦЕСУАЛЬНИХ СПРАВ
}

У статті досліджено саму суть визначення «медіація», причини введення медіації та питання стосовно процедури медіації під час вирішення цивільно-процесуальних справ.

$\mathrm{y}$ нашій державі існує традиційна форма для захисту прав і свобод особи й порушуваних інтересів, яка закріплена основним законом - Конституцією України. Спори в різних відносинах, а саме цивільних, трудових і господарських, вирішуються через суд. Судова система займає провідну роль у нашому суспільстві. У різних країнах використовується різні механізми, а саме третейський суд, переговори й арбітрування. У США медіація використовується із 60 -х років минулого століття. 3 того моменту медіація поширювалася на території різних держав, тому що вона виявилась дійовою альтернативою судового розгляду. Але в Україні не широко використовується інститут медіації з певних причин. А саме:

- по-перше, не врегульовано на законодавчому рівні саме прийняття закону «Про медіацію»;

- по-друге, психологічно наше суспільство не готово звертатися за допомогою до медіаторів.

Тема складна й багатогранна й розглядається такими дослідниками різних ступенів кваліфікації та різних років, як С. БондаренкоЗелінська, Г. Запара, Н. Гончарова, В. Мотиль, М. Дякович, В. Землянська, В. Комаров, Д. Подковенко, Л. Андрієвська, С. Дяченко, Н. Килинник, I. Ковальчук, Г. Єременко, М. Поліщук, Н. Мазаракі, В. Кудрявцева, Ю. Притика, Ю. Зазуляк, Т. Кисельова.

Як зауважив Х. Бесемер, медіація - це технологія, яка допомагає вирішити конфлікт за участю третьої сторони [1]. За кордоном почали використовувати медіацію як результат розуміння народом необхідності. Конфліктні трудові ситуації розглядалися особливими комісіями разом із представниками трудових колективів. Країни за правовою системою можна поділити на дві частини:

- країни, де в основі лежить римське право.
Там використовуються романо-германську сім'ю континентального права;

- країни, де в основі лежить англо-саксонська сім'я загального права [2].

Насамперед ми повинні сказати, що є відмінність між поняттями «цивільне право» й «загальне право»:

- у країнах, де використовується загальне право, судовий розгляд використовується лише в кінці спору;

- оцінювати факти й встановлювати може лише суд присяжних;

- кожну годину потрібно платити адвокату за участь у справі, таким чином, це сповільнюе процес;

Обидві сторони несуть судові витрати незалежно від результату [3].

У країнах, де є загальне право (США, Австрія та Канада, Англія), використовують медіацію в приватному секторі. Навпаки, інші країни, які використовують систему цивільного права (Hiмеччина, Чехія та Швейцарія) виявили не бажання використовувати медіацію на перших порах, але пізніше визнали.

В Україні дуже складно проходять дискусії стосовно медіації. Як зазначає Н. Бондаренко-Зелінська, натепер у нашій країні провідною роллю була й буде судова система захисту, у фундамент якої покладено змагальний фактор [4]. Медіація $є$ для нашого суспільства й нашої країни новим явищем. Будь-яка особа має право на захист їі порушених прав згідно з Основним Законом України.

Права й свободи людини й громадянина захищаються судом. Кожному гарантується право на оскарження в суді рішень, дій чи бездіяльності органів державної влади, органів місцевого самоврядування, посадових і службових осіб [5].

Сумно говорити про те, що нині в Україні немає профільного закону стосовно регулювання важливих аспектів процедури посередництва, але законодавство нашої країни має декілька реформ, що є основною практичного застосування. 
У 2015 році Верховна Рада України прийняла проєкт декількох реформ стосовно медіації, а саме «Закон про медіацію». За основу було взято законопроєкт № 3665 , який навіть пройшов у першому читанні, але був відхилений і відкликаний із розгляду 28 лютого 2019 року [6]. Як зауважив Н. Килинник, медіація може використовуватися у сферах цивільних і сімейних, зокрема в сімейних спорах. Лише через медіацію можливо укріпити інститут родини в Україні [7]. Науковець Т. Цувіна поділяє медіацію на групи:

1. Присудову;

2. Досудову.

Присудова медіація - це перший вид медіації, що проводиться одразу після звернення особи до суду. Вона інтегрована в цивільне судочинство. На відміну від досудової медіації, що проводиться без звернення до суду, вона поділяється на зовнішню та внутрішню присудову медіацію [8].

Існують елементи медіації:

- конфліктні сторони самі обирають спосіб процедури посередництва.

- наявність людини, яка буде займатися посередництвом під час вирішення суперечок (медіатора).

- потрібно визначити мету самої медіації, тобто знайти компроміс.

Головною причиною не застосування в Україні медіації є відсутність єдиної думки щодо введення медіації в правову систему. Одні фахівці говорять про доцільність медіації, а інші говорять протилежне. Вони кажуть, що медіація є суттєво комерційною діяльністю. Існують дві концепції стосовно запровадження медіації в національну правову систему:

- по-перше, судова концепція, тобто судова медіація повинна стати головним елементом процесуальної процедури;

- по-друге, медіація - автономний спосіб розв'язання конфліктів.

Але слід зазначити, що існує альтернативний розгляд справ, а саме третейські суди, арбітражні керівники, також у цивільному процесі є вирішення справи за участю судді й мирова угода.

Що стосується цивільного процесу, то чинне українське законодавство заклало основи запровадження медіації, передбачивши можливість укладення мирової угоди. Насамперед ми повинні звернутися до чинного цивільного кодексу України. Стаття 207 Цивільно-процесуального кодексу (далі - ЦПК): Мирова угода укладається сторонами з метою врегулювання спору на підставі взаємних поступок і має стосуватися лише прав та обов'язків сторін.

$\mathrm{У}$ мировій угоді сторони можуть вийти за межі предмета спору за умови, якщо мирова угода не порушує прав чи охоронюваних законом інтересів третіх осіб. Сторони можуть укласти мирову угоду й повідомити про це суд, зробивши спільну письмову заяву, на будь-якій стадії судового процесу.

Суд постановляє ухвалу про відмову в затверджені мирової угоди й продовжує судовий розгляд, якщо умови мирової угоди суперечать закону чи порушують права чи охоронювані законом інтереси інших осіб, є не виконуваними, а також одну зі сторін мирової угоди репрезентує іï законний представник, дії якого суперечать інтересам особи, яку він представляє.

У статті 203 ЦПК зазначається порядок проведення врегулювання спору за участі судді. Проведення врегулювання спору за участю судді здійснюється у формі спільних і (або) закритих нарад. Сторони мають право брати участь у таких нарадах у режимі відеоконференції в порядку, визначеному ЦПК. Спільні наради проводяться за участю всіх сторін, їх представників і судді. Закриті наради проводяться за ініціативою судді з кожною зі сторін окремо. У рамках проведення спільних і закритих нарад суддя наділений такими повноваженнями:

1) роз'яснення прав та обов'язків сторін;

2) роз'яснення сторонам порядку й особливостей проведення врегулювання спору за участю судді;

3) роз'яснення предмета доказування щодо категорії спору, що розглядається;

4) з'ясування предмета, підстав позову, підстав заперечень;

5) порада сторонам надати пропозиції щодо мирного врегулювання спору або самостійне представлення суддею варіанту мирного врегулювання;

6) звернення уваги на судову практику в аналогічних справах, але виключно в рамках закритих (окремих) нарад.

Під час проведення врегулювання спору судді заборонено оцінювати докази й давати сторонам конкретні юридичні поради й рекомендації [9].

Указані положення процесуального законодавства викликають у фахової спільноти численні дискусії щодо нечітких меж між правом судді на надання роз'яснень сторонам, у тому числі про наявність судової практики зі спірного питання, та забороною надавати юридичні поради й оцінку доказів, із чим неможливо не погодитися та що потребує уточнення на законодавчому рівні.

Будь-яка інформація, отримана стороною, а також суддею під час проведення врегулювання спору, є конфіденційною. Протоколи нарад не ведуться, не здійснюється їх фіксування технічними засобами.

Наслідки врегулювання спору за участю судді будуть різні залежно від того, пройшла процедура успішно чи ні. Якщо врегулювання було успішним, наслідком буде: 
- мирова угода (затверджена судом);

- залишення позову без розгляду;

- відмова від позову позивачем;

- визнання позову відповідачем.

Якщо врегулювання не було успішним, наслідком буде:

- припинення процедури за ініціативою судді, якщо одна зі сторін умисно й свідомо затягує час;

- припинення процедури за заявою однієї зі сторін;

- припинення процедури із закінченням встановленого 30-денного строку [9].

Висновки. Отже, дослідивши вище сказану інформацію, можна зробити висновок що медіація $€$ вагомим механізмом під час вирішення конфліктів і спорів. Медіація може допомогти судовій системі й зробити її досконалішою. Є певні підстави для введення медіації в українську систему для поліпшення законодавства. Окрім того, на прикладі інших країн, які використовують альтернативний спосіб - медіацію, можна зробити висновки, що така практика актуальна й ефективна. Але ми повинні розуміти, що розв'язання спорів $€$ досить складним і багатогранним питанням, тим паче якщо вона вводиться до однієї з гілок влади - судової. До медіації потрібно підходити дуже обачливо й відповідально. Впровадження медіації в цивільний процес України - дуже складний процес тому, що правова культура населення незначна, немає довіри до медіації та правової бази й підтримки з боку фінансів.

\section{Jimepamypa}

1. Єрьоменко Г. Матеріали курсу підготовки медіаторів із кола посадовців, які займають керівні посади в органах виконавчої, законодавчої та судової влади. Спільна програла Європейської Комісії та Ради Європи «Прозорість та ефективність судової систели України». Київ. 2010.

2. Михальський Ю. Інститут медіації в Україні та за кордоном. Юридична газета. 2011. № 5 (270).

3. Бондаренко-Зелінська Н.Л. Впровадження медіації у судовий процес як складова наближення законодавства України до Європейський стандартів. Приватне право $i$ підприєлництво. 2011. Вип. 10. С. 181-185.

4. Цивільний процесуальний кодекс України : Закон України від 18 березня 2004 р. № 1618-IV (станом на 01 березня 2019 р.) / Верховна Рада України. Харків : Право. 2019. 253 с.

5. Проєкт Закону про медіацію від 27 березня 2015 р № 2480. База даних «Законодавство України». URL: http://w1.c1.rada.gov.ua/pls/zweb2/ webproc4_1?pf3511=54558.

6. Килинник Н., Ковальчук I. Застосування інституту медіації в справах про розірвання шлюбу. Підприємниитво, господарство $і$ право. 2019. № 5. С. 24-27.

7. Цувіна Т. Впровадження інституту присудової медіації як перспективний напрямок реформування цивільного процесуального законодавства України.
Україна на шляху до Європи: рефорла иивільного проиесуального законодавства : Збірник наукових праць. 2017. C. 195-200.

8. Цивільний процесуальний кодекс України : Закон України від 18 березня 2004 р. № 1618-IV (у редакції від 18 березня 2004 р.) / Верховна Рада України. Відомості Верховної Ради України. 2004. № 40-42. Ст. 492.

9. Цивільний Кодекс України : Закон України від 16 січня 2003 р. № 435-IV / Верховна Рада України. URL: https://zakon.rada.gov.ua/laws/card/435-15.

\section{Анотація}

Косяченко К. Е., Черепанов М. М. Процедура медіації у вирішенні цивільно-процесуальних справ. - Стаття.

Кожна країна має судову систему, яка відіграє найважливішу роль у суспільних відносинах. Судова система України характеризується ефективністю захисту прав і свобод людини й громадянина відповідно до закону. Але судова система змінюється протягом усього терміну незалежної держави через певні реформи й зміни. Незважаючи на певні реформи й зміни, нині судова гілка має проблеми. Тобто суди дуже навантажені, і тим самим порушуються строки судового розгляду.

Головною варіацією розв'язання такого питання є розгляд і розвиток альтернативних способів, серед яких є інститут медіації. Насамперед слово «медіація» означає «посередництво». У психології дослідники вивчають медіацію як своєрідність форми розв'язання спірних моментів і конфліктів. Тобто медіація визначається як добровільний і конфіденційний спосіб розв'язання конфліктів, медіатор сприяє учасникам ситуації почати прямі перемовини задля розв'язання проблеми. Існують певні ознаки медіації, а саме конфіденційність і структурована процедура проведення.

Цивільноправові відносини $є$ найширшою сферою застосування медіації. Рекомендація Комітету міністрів державам-членам Ради Європи № 10 від 18 вересня 2002 р. про медіацію в цивільних справах, базуючись на концептуальних засадах попередньо прийнятих актів Ради Європи, звертається до запровадження медіації в комерційних і трудових спорах, справах про захист прав споживачів. Вочевидь, її розробники розуміли, що запровадження медіації у сфері бізнесу є оптимальним підходом, адже він здатний забезпечити добровільне находження компромісного, найбільш прийнятного для обох сторін рішення, що ухвалене в конфіденційний спосіб. Зрозуміло, що за таких умов бізнес-відносини тільки виграватимуть від застосування медіації як із боку економічної вигоди, так і в контексті раціональної перспективи збереження партнерських і дружніх відносин між сторонами спору.

Ключові слова: медіація, судова реформа, альтернативне вирішення справ, медіатор, примирення.

\section{Summary}

Kosiachenko K. E., Cherepanov M. M. Mediation procedure in resolving civil proceedings. - Article.

Every country has a judicial system that plays a crucial role in public relations. The judicial system of Ukraine is characterized by the effectiveness of protection of human and civil rights and freedoms in accordance with the law. However, the judiciary is changing throughout the term of an independent state due to certain reforms and changes. Despite some reforms and changes, the judiciary is 
currently in trouble. That is, the courts are very busy and thus violate the terms of the trial.

The main variation in solving this issue is the consideration and development of alternative methods, among which is the institution of mediation. First of all, the word "mediation" means "mediation". In psychology, researchers study mediation as a kind of form of resolving disputes and conflicts. That is, mediation is defined as a voluntary and confidential way of resolving conflicts, the mediator helps the participant to start direct negotiations to resolve the problem. There are certain signs of mediation, namely: confidentiality and a structured procedure.

Civil law relations are the broadest field of mediation. The Recommendation of the Committee of Ministers to the member states of the Council of Europe № 10 of 18 September 2002 on mediation in civil matters, based on the conceptual framework of previously adopted acts of the Council of Europe, calls for the introduction of mediation in commercial and labor disputes, consumer protection cases. Obviously, its developers understood that the introduction of mediation in the field of business is the best approach, because it is able to ensure the voluntary finding of a compromise, the most acceptable to both parties, a decision taken in a confidential manner. It is clear that under such conditions, business relations will only benefit from the use of mediation, both in terms of economic benefits and in the context of a rational perspective of maintaining partnership and friendly relations between the parties to the dispute.

Key words: mediation, judicial reform, alternative resolution, mediator, reconciliation. 